\section{ECOHSTOR}

Make Your Publications Visible.
A Service of

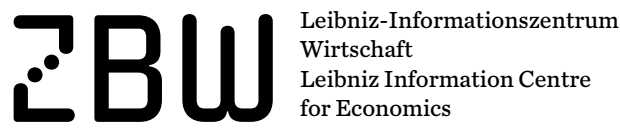

Kohnert, Dirk

\title{
Conference Paper \\ Donor's double talk undermines African agency : Comparative study of civic agency in Burkina Faso and Togo
}

Suggested Citation: Kohnert, Dirk (2015) : Donor's double talk undermines African agency : Comparative study of civic agency in Burkina Faso and Togo, The fabrication of public action in countries «under an aid regime» APAD 2015 International Conference, Cotonou, 17-20 November 2015, At Cotonou, Benin Republic, West Africa, ZBW - Deutsche Zentralbibliothek für Wirtschaftswissenschaften, Leibniz-Informationszentrum Wirtschaft, Kiel und Hamburg, http://dx.doi.org/10.13140/RG.2.1.1046.0880

This Version is available at: http://hdl.handle.net/10419/120921

\section{Standard-Nutzungsbedingungen:}

Die Dokumente auf EconStor dürfen zu eigenen wissenschaftlichen Zwecken und zum Privatgebrauch gespeichert und kopiert werden.

Sie dürfen die Dokumente nicht für öffentliche oder kommerzielle Zwecke vervielfältigen, öffentlich ausstellen, öffentlich zugänglich machen, vertreiben oder anderweitig nutzen.

Sofern die Verfasser die Dokumente unter Open-Content-Lizenzen (insbesondere CC-Lizenzen) zur Verfügung gestellt haben sollten, gelten abweichend von diesen Nutzungsbedingungen die in der dort genannten Lizenz gewährten Nutzungsrechte.
Terms of use:

Documents in EconStor may be saved and copied for your personal and scholarly purposes.

You are not to copy documents for public or commercial purposes, to exhibit the documents publicly, to make them publicly available on the internet, or to distribute or otherwise use the documents in public.

If the documents have been made available under an Open Content Licence (especially Creative Commons Licences), you may exercise further usage rights as specified in the indicated licence. 


\title{
Donor's double talk undermines African agency
}

\author{
Comparative study of civic agency in Burkina Faso and Togo
}

Draft, not to be quoted without permission of the author

Dirk Kohnert ${ }^{1}$

\begin{abstract}
Despite a long-standing controversy about aid-effectiveness in general and the impact of aiddependency on governance in particular, little is known on the effect of donors policies on civic agency for democratization in aid dependent autocratic regimes. In this study it is argued that the long-term effects of double-talk of donors, who openly promote democracy and freedom but covertly follow overriding hidden interest, are a neglected source of failure of civic protest and democratic revolutions in autocratic regimes. The differing outcome of 'democratic revolutions' in Togo and Burkina Faso - both 'aid darlings' for decades - serves to substantiate this thesis. A systematic and holistic consideration is necessary for an unbiased evaluation of the hidden adverse impact of aid on collective action at the grass-roots. Therefore, a rethinking of temporal and disciplinary 'fault lines' in development politics as well as in development studies is essential.
\end{abstract}

\section{Résumé}

Le double langage des bailleurs sape la responsabilité civique africaine contre des régimes autocrates: Étude comparative au Burkina Faso et au Togo: En dépit d'une longue controverse à propos de l' efficacité de l'aide en général et de l'impact de la dépendance à l'égard de l'aide sur la gouvernance en particulier, on en sait peu sur l'effet à long-terme des politiques des bailleurs sur la capacité civique d'agir en faveur de la démocratisation des régimes autocrates dépendants de l'aide. Dans cette étude, notre hypothèse est que le double langage des bailleurs de fonds qui met ouvertement en avant la démocratie et la liberté mais suit secrètement des intérêts plus déterminants/lucratifs, est une source négligée de l'échec des protestations de la société civile et des révolutions démocratiques au sein des régimes autocratiques africains. Les différents résultats des "révolutions démocratiques» au Togo et au Burkina Faso - les deux "chouchous des bailleurs» ces dernières décennies - confirment cette hypothèse. Une évaluation de l'impact latent de I'aide sur l'action collective au niveau local n'est possible que par une approche systématique et complète de la situation. Ainsi, un réexamen des lignes de faille au cours du temps et disciplinaires tant au niveau des politiques de développement que dans les études sur le développement s'avère essentiel..

Keywords: Development cooperation, democratization, civic agency, autocratic regimes, Burkina Faso, Togo, West Africa, ODA, aid dependency

JEL code: F35, F54, F68, N47, N97, 021, 035, Z13

\footnotetext{
${ }^{1}$ Institute of African Affairs, GIGA - German Institute of Global and Area Studies, Hamburg/Germany.

E-mail : Kohnert@giga-hamburg.de.
} 


\section{Introduction}

Much has been written on the impact of aid on governance and democratization in Africa but little is known on the effect of aid on civic agency against autocratic African rulers. There exists a long-standing controversy whether official development aid (ODA) could improve effectively governance or not (Bingsten \& Tengstam 2015; Birsdall \& Kharas 2010; Brätigam \& Knack 2004; Collier 2006; Knack 2004; 2001). According to Djankov et al (2008) aid constitutes an even bigger curse than oil. However, more recent studies suggest that aid can play a positive role at least under certain conditions, namely when its components are considered (Ear 2007). Aid was effective at promoting democratic transitions during the second wave of democratization in Sub-Saharan Africa in the 1990s at least in some aid dependent countries that faced deep economic crisis and public discontent. But it failed in most cases to consolidate democracy and good government. At best it contributed to institutionalizing procedural multi-party systems and formal democracy, however in most cases it failed to change informal politics that upheld autocratic rule. Most empirical studies on the determinants of aid conclude that geo-political ties and self-interest of donors still outweigh other factors, including need of the recipient countries although the latter attracted growing attention since the end of the Cold War (Rogerson \& Steensen, 2009:1). Hoeffler and Outram (2008) found out that almost half of the predicted value of aid was determined by donor-specific factors, $36 \%$ by needs, $16 \%$ by donor's self-interest. Recipient's performance, measured by growth, democracy and human rights, accounted for just $2 \%$.

Large amounts of aid to countries with weak institutions can even create those institutional problems that lead to ineffectiveness (Bräutigam, 2000). Apparently, there exists a trade-of between the objectives of aid promoted economic growth and democratization, even if inclusive growth had been targeted (Resnick \& de Walle 2013; Resnick 2012: 2-3). In addition, aid unpredictability weakens governance by providing incentives to corrupt leaders to engage in rent-seeking (Kangoye 2013). A recent comparative analysis of EU development aid in 17 African countries revealed that strategic allies as well as good growth performers were shielded against necessary sanctions, actually required because of undemocratic governance and human rights violations (Del Biondo 2015). Competing commercial and strategic interests prevent donors from making a more positive contribution (Brown 2004). Due to internal strives between different EU departments and member countries as well as a rather technocratic bias the EU had problems to render aid more effective (Hackenesch, 2015; Kohnert 2004).

Concerning authoritarian political systems, many donors prefer to give aid to civic groups, but whether these act in general more efficiently than state institutions is 
questionable (Kohnert 2004a). The Paris Declaration of 2005, the Accra Agenda for Action (2008) and the "Busan Partnership for Effective Development Cooperation" (2011) were important steps to make aid more efficient by a better coordination and harmonization of donor policies (Davies \& Klasen 2013), meant last but not least to reduce the risk of elite capture (Bigsten \& Tengstam 2015:75). Equally important were the focus on recipient country ownership and promotion of inclusive development partnerships, thus opening up also for new players from the civil society.

Nevertheless, the half-life period of the institutional memory both of development agencies and related research and evaluation institutions is still quite short. In contrast, failures of development projects and misguided development policies remain reflected usually by the local population concerned over generations. However, its long-lasting impact is considered by the donors only occasionally. A systematic and holistic consideration is a perquisite for an unbiased evaluation of the impact of aid at the grass-roots. Therefore, a rethinking of temporal and disciplinary 'fault lines' in development politics as well as in development studies is essential too. Last, but not least, a major change in the methodology of development planning is required. This is closely connected with a shift of emphasis in the approach to development cooperation, away from project service delivery, towards supporting the socio-cultural and political environment of the recipient communities. This demands a reorientation of aid management, away from the blinkers of result-orientated planning towards participative organizational cultures of learning embracing all partners on a level playing field (Kohnert 2006:1; Kohnert \& Preuss 2003).

In contrast to the rich body of literature on the influence of aid on governance, the impact of aid (directly or indirectly) on civic agency against autocratic rule has received little scholarly attention. Much has been written about the Arab spring and its repercussions on Sub-Saharan Africa (e.g. Burundi, Burkina Faso, Senegal, Togo) and elsewhere. However, the impact of aid on civic agency is mentioned only casually if at all in the studies named above (Resnick 2012:4, 7, 10-12) and more explicitly by Blair (2004) and Hearn \& Robinson (2000). Resnick (2012; Resnick \&de Walle, 2013) proposed a typology of protest wave outcomes, including democratic revolutions, democratic reform movements and stolen revolutions. Most of these protest waves failed, less than $29 \%$ succeeded, i.e. improved democracy. In addition, civil society organizations act not necessarily pro-democracy, even if they pretend to belong to grass-roots protest movements ${ }^{2}$. Recent scholarly investigations showed a

\footnotetext{
${ }^{2}$ In Burkina Faso for example, Herman Badolo, the leader of the anti-referendum collective that opposed the autocratic president's attempts to extend his rule further and founder of the l'Alliance pour la défense de la démocratie (ADP), was accused in the aftermath of the failed reactionary coup of September 2015 of backing the coup leaders ("Burkina : deux leaders politiques proches de l'ex-président Compaoré interpellés", Voice of America, French service, 6 Oct. 2015)
} 
rather ambiguous situation. CSOs in developing countries are not necessarily to be considered as the cradle of democratization but on the contrary actively backing despotic regimes (Bunk \& Lorch \& Wischermann 2015). Why then do protest movements and CSOs fail? Is there a common rationale behind this failure. This is still an open question. The subsequent study is meant to contribute to its solution.

That being said, I should like to introduce shortly some underlying assumptions and definitions. It seems reasonable to assume that a positive impact of aid on civic agency is c. p. more pronounced in aid dependent than in resource rich authoritarian regimes because the latter are less prone to political pressure attached to the conditionality of aid. In addition, multi- and bilateral ODA is c. p. less likely to build-up civic agency against despotic rulers than that of international non-government organizations (NGOs) because non-state agencies, like the political foundations in Germany, might have more leeway vis à vis assistance of political opponents than state institutions.

'Aid dependency' is a multidimensional category and difficult to measure. There exist no single agreed definition. Following Bräutigam (2000:2), I shall use, a simple quantitative measure in the subsequent chapters, i.e. countries receiving aid at levels of more than ten percent of GNI for more than four subsequent years on the medium and long run as a proxy 3 .

The concept of 'civil society' gained momentum only in the post Cold-War period that tried to open society against autocracy and one-party rule. Civil society Organizations (CSOs) and African social movements were endowed an important role in opposing autocratic regimes, notably in the African context where informal politics are crucial for the interaction between the state and its citizens (Obadare \& Willems 2014:3; Eberlei 2014). The development of civic agency has been seen by some scholars as the central political problem of the 21st century ${ }^{4}$. However, the normative concept of 'civic agency' is not straightforward. It is related to Western rights-based views, notably, on the relationship between polity and the state in general and democracy in particular (Fowler 2009:150-151).

\footnotetext{
3“On average, low-income countries received just under one percent of GNP in aid in 1997. But aid equaled 10 percent or more of GNP in more than 30 countries with populations over 1 million. Trends in aid as a percentage of GNP indicate that aid intensity has been on the rise since 1975, although it appears to have leveled off slightly since 1992." (Bräutigam 2000: 2)

4 "The central problem of the 21st century is the development of civic agency. Civic agency is the capacity of human communities and groups to act cooperatively and collectively on common problems across their differences of view. It involves questions of institutional design (that is, how to constitute groups, institutions, and societies for effective and sustainable collective action) as well as individual civic skills. Civic agency can also be understood in cultural terms, as practices, habits, norms, symbols and ways of life that enhance or diminish capacities for collective action." "Building civic agency: the public-work approach". Harry C. Boyte, 21 November 2007.
} 
Thus, the ascription of civic agency is dependent last, but not least on power relations on the continuum from a local to a global order and thus on the signification of labelling ${ }^{5}$. As a rule, civic agency in autocratic regimes is met by repression. Below I prefer to use an inclusive definition of repression as "any action by another group which raises the contender's cost of collective action" (Till 1978:100, quoted by Earl 2003:46). In this sense repression has multiple dimensions that involve not just the state, but also private institutions and agents, as well as different modes of repression, either by coercion or by channeling, and hidden vs. observable repressive actions, as explained in detail by Jennifer Earl (2003). The crux is that generally donors do not bother or do not spot and understand indirect and hidden forms of repression and therefore do not act against it.

In the following I shall focus on a comparative study of two neighboring West African countries, both 'aid darlings' with a rich tradition in grass-root protest against autocratic rulers that resulted in different outcomes. That in Burkina Faso succeeded ${ }^{6}$ and served as model for people in other African countries that suffered from autocratic rule, whereas the popular protests in Togo failed.

\section{Comparative analyses of Burkina Faso and Togo}

Both Burkina Faso (BF) and Togo were relatively (in comparison to other LDCs) 'over-aided' in view of its institutional performance over decades: ODA as \% of GNI received averaged 11.7\% for BF and $10.1 \%$ for Togo (1980 to 2013; cf. Table 1, Annex). Both regimes obtained most of the time legitimacy rather by external powers and foreign assistance than by their own people. Civic and political action against autocratic rule has been a recurrent feature of domestic policy in both countries. At least three peak-waves of democratic protest in Togo and BF have been identified (Franklin 2014): In Togo 1991, 2005, 2010 and in BF 1999, 2002, 2011. Whereas civic agency gathered a strong momentum in BF and finally overthrew the autocratic ruler on 31 October 2014, it was frustrated after repeated 'democratic revolutions' against the despotic Gnassingbé-Clan whose power was consolidated over decades by donor support. Whether the 'democratic revolution' in BF could serve as model and example for other African countries is open to question (Van Wyk 2015).

\footnotetext{
${ }^{5}$ Moncrieffe \& Eyben, 2007, quoted in Fowler 2009, 151. - Below I shall refer to Alan Fowler's working definition: "Civic agency is a predisposition toward, and a capability for, leading life together with others in a society and being concerned for the whole. Agency which is considered civic incorporates a basic principle of an equitable, democratic society." (Fowler, A. 2009:151).

${ }^{6}$ At least up to the time of finishing this paper when the transitional government was ousted by a coup, cf. below.
} 


\section{(1) Case study Burkina Faso}

\section{a. $\quad$ Long-term aid dependency matters}

Burkina Faso has never seen a peaceful transition of power since independence. It counts among the eight poorest countries of the world. It realized a per capita income of $\$ 670$ in 2013 , but growth was not inclusive with a poverty rate of about $46 \%$ in 2009. According to the Human Development Index (2014) the country ranked 181st out of 187 countries.

Aid dependency of BF during the last decades was generally high but especially pronounced during the 1990s with an average of $16,1 \%$ of GNI (cf. Tab. 1). In most years of the 2000s and probably also of the 1990s ODA received was equal or surpassed central government expense, financed by the government's own resources (Tab. 2). Aid was given by a total of over 100 donors in the country, and BF receives a large share of its aid as general budget support since the reorientation of donors aid policy in 2004 (WB 2009:25).

Since independence BF and the former colonial power France continued a kind of patron-client relationship, basically based and trade and aid (Rupley et al 2013:43-48). France was the most important donor of bilateral aid. French aid represented about $25 \%$ of total aid received up to the mid 1990s (Gabas et al 1997:49). Paris mostly opposed political conditionality if the latter did not correspond with its national self-interest and for example almost never included human rights clauses (Felice 2015:38). The general approach of bilateral project aid was centralized ${ }^{7}$ and dominated by a subculture of economists and diplomats (Felice 2015:37), with an clear economistic bias and orientated versus modernization and technology transfer. Double talk prevailed in relation to the overall aims of development assistance (apart from military cooperation). Improvement of the living conditions of ordinary citizens was generally the declared $\operatorname{aim}^{8}$, however this was subordinated to overriding national, commercial and geo-political interests of the Messieurs Afrique and the WAEMU (Kohnert 2005). Thus, French ODA fell sharply during the Sankaraera (1983-87) that did not suit French national interest as seen by Paris (Gabas, J.J. et al 1997:43-48). France ranks so far still at the bottom of international ranking in aid transparency (Barbière 2014).

\footnotetext{
7 "The central steering of aid projects hinders a general domestic approach to development actions and problems." (Gabas et al 1998:49)

${ }^{8}$ BF still belongs to the 16 priority countries suffering from poverty (PPPs). "France focuses its efforts on solidarity grants. It mobilizes its bilateral and multilateral instruments to help meet all of its development policy objectives, including: The Millennium Development Goals (MDGs), economic development, democratic governance and rule of law, Preservation of environmental capital." (France Diplomatie, 2015).
} 
In a coup d' état of 1987 Blaise Compaoré, supported by France, seized power from his murdered predecessor Thomas Sankara. The coup was justified by Compaoré in saying that Sankara had jeopardized foreign relations with France and neighboring Côte d'Ivoire (BFwikipedia), one of the pillars of the pré-carré of French foreign policy in Africa. The fact, that Compaoré could stay in power over 27 years was again due last, but not least, to the unwavering support of major donors, above all France.

\section{b. The development of civic agency in Burkina Faso}

Under the pressure of a popular protest movement Compaore fled the country with French assistance on 31 October 2014 after 27 years of autocratic rule. This was the second time in the country's history that radical masses induced the end to a despotic regime. The first insurrection of the Burkinabé people took place on 3 January 1966 putting an end to the 1st republic (Chouli, 2014).

These popular protest movements were enabled by a deeply engrained civic 'counter public sphere' (Gegenöffentlichkeit, Oskar Negt) that the Burkinabé had developed since colonial times which had strong undercurrents against all forms of neo-colonialism (Chouli 2014a: 148). The driving forces and ideologies of this civic Gegenöffentlichkeit came to the forefront in its most visible form during the short reign of Sankara and left a permanent impression on the country so far (Haskin 2015). The quest for a "democratic and popular revolution", strongly influenced by leftist and pan-Africanist ideas, was the main pillar of Sankarism. This has little to do with Western concepts of liberal democracy and human rights but rather with self-reliance, inclusive growth 'from below', personal integrity of political leaders and national African dignity, as envisaged by Sankara, when he renamed Upper Volta (1984) in Burkina Faso, i.e. "The Land of Upright Men".

Many ordinary Burkinabé citizen still today regard development under Sankara a great success despite undeniable human rights abuses. ${ }^{9}$ He became the hero of the men on the streets, the jobless school leavers, the oppositional Young Turks and last, but not least of modern griots like the rap singer 'Smockey' who co-founded the non-violent Burkinabé protest movement Balai citoyen (civic broom) and the Africa wide platform Tournons la page (let's turn the tide) that established a branch also in Togo (Commeillas, 2015). Thus allusions

\footnotetext{
9 "The infant mortality rate was brought down to less than 150 out of 1.000 births; millions of vaccinations were given; women were given a comprehensive set of legal rights and were granted government representation. Perhaps most amazingly, the redistribution of land away from feudal lords made food production so efficient that within four years, Burkina Faso went from heavy dependence of foreign aid for basic nutrition to running a food surplus." (Haskin 2015:1).
} 
to Sankarism became the moral driving force behind the democratic revolution in 2014 (Frére et al 2015: 301-04; Haskin 2015).

In a nutshell, the civic Gegenöffentlichkeit in BF was developed in contrast, if not in open opposition to the foreign aid policy of donors who assisted their 'aid darling' BF massively over decades as explained above. Civic agency developed in spite of the official development rhetoric that became progressively participative and pro-poor orientated in the course of the past decades. However, although major donors increasingly try to assist civic movements in LDCs this is hardly possible without the consent of the regime in place. Yet, despotic regimes are suspicious vis à vis such endeavors and have a close eye that only those CSO get foreign assistance that constitute no danger to their own power base.

Nevertheless, donors self-interest and double talk is only one important, although neglected factor among others that obstruct civic agency to develop. Why then, the civic protest movements in BF succeeded in toppling an autocratic regime despite countervailing donor policies and in Togo it did not?

Mass protest both in BF and Togo were triggered last, but not least by trans-national factors, like the Sahel drought in the 1970s and 1980s and the aftermath of the 2008 global financial crisis on Sub-Saharan Africa. However, these protest should not be interpreted just as local reaction to overpowering global forces. In view of the worldwide spread of political concepts of good governance and the responsibility of own governments to tackle global crisis the construction of close linkages of responsibility by drivers of change like the rap singer 'Smockey' ${ }^{10}$ who spearhead the mass protest became part of the game (Engels, 2015a:181; 2015b; 2015).

However, on 16 September 2015, General Gilbert Diendéré, long-term chief of the security service und commander of the presidential guard (Régiment de sécurité présidentielle, RSP) of Compaoré, staged a coup d'état. Diendéré, still éminence grise of the RSP since his dismissal as chief of the RSP by the transitory government in Nov. 2014, was the commander of the unit which killed Sankara in 1987 and thereby initiated the coup d'état of Compaoré. Moreover, he was accused of being involved in the assassination of the journalist Norbert Zongo, director of the weekly L'Indépendant in 1998 by the RSP which triggered widespread civil protest. Diendéré, who was still in charge of the anti-terrorist unit was said to maintain excellent relations to French and American military networks. The renewed coup of 2015 came after the Truth and Reconciliation Commission recommended

\footnotetext{
10 "Popular music, as a discursive terrain, is a site at which power is enacted, acknowledged,
} accommodated, signified, contested, and resisted" (Averill 1997: xi-xv; cf. Kohnert 2011a; Prause, 2013). 
the disbanding of the presidential guard and the exclusion of discredited key allies of ousted Compaoré from the forthcoming elections. Civic movements like Balai Citoyen organized widespread popular resistance and were joint in its call by trans-national networks in- and outside Africa. One week later, the coup-leaders gave up under the pressure both of the civil society resistance movements and that of the national army and the international community. Diendéré admitted during a press-conference on 23 September: "We saw what happened. We knew that the people were not favorable. That's why we have simply abandoned ${ }^{11}$. Michel Kafando, the president of the interim government, reinstalled on 23 September, seconded "We are proud of the mobilisation and fearlessness of the people of Burkina Faso, in particular of its youth, whose determination has stopped the coup succeeding." (BBC-news Africa, 24.09.15). Although the coup and its background still await more detailed scholarly analyses, preliminary findings indicate that grass-root civic protest movements, especially of the youth, that succeeded in encouraging the regular army to side with the protesters, were more effective in restoring democracy than the actions of the power-hungry elite ${ }^{12}$. This was the second time within a year that the pro-active Gegenöffentlichkeit of BF ousted their autocratic rulers.

All the same, there were more specific common causes of popular protest movements in BF and Togo like the lack of prospects of jobless school leavers, rising food and fuel prices and the deteriorating situation of the poor and the descending lower middle class. However, the mass protest in BF had its peculiarities that make it unlikely to be shared by other African countries. It was not just a protest against autocratic rule and denied human rights but also an aspiration to regain the progress experienced during the glorious times of Sankara, whether unduly transfigured or not (Haskin 2015).

\section{(2) Case study Togo}

\section{a. Long-term aid dependency matters ${ }^{13}$}

Civic agency in Togo is not to be understood without recourse to Togo's history of development co-operation since independence (1960). The aftermath of an unholy alliance

\footnotetext{
11 “" Le coup d'État s'est fait compte tenu d'un certain nombre de raisons que nous avons évoquées lors de la proclamation (du putsch). Nous avons vu ce qui s'est passé. Nous avons su que le peuple n'était pas favorable. C'est pour ça que nous avons tout simplement abandonné » (Jeune Afrique, 23. Sept. 2015)

${ }^{12}$ See BBC-news-Africa: "Seven lessons from Burkina Faso's seven-day coup." 24 September 2015 and AC 2015.

13 To keep references in this paper in reasonable limits and to prevent overlength of the paper, references on the political situation in Tog are mainly restricted to earlier own publications; for more detailed references please consult these publications.
} 
of misguided post-colonial Africa policy over decades and the quest of African autocrats for unlimited personal power still impedes the development of a powerful and challenging Gegenöffentlichkeit in Togo .

The murder of its first president, Sylvanus Olympio, on 13 January 1963 by a group of Togolese veterans of the French colonial army, led by Sergeant Etienne Gnassingbé (later called Eyadéma) and tolerated, if not instigated, by the former French colonial power, opened up a Pandora's box. It was the first violent coup in the history of independent subSaharan Africa. Although unanimously condemned by the donor community and the Organization of African Unity (OAU), both turned back to business as usual soon (Kohnert 2011). The autocratic rule of Eyadéma, formally installed in 1967, was generously supported by major donors, notably the former colonial powers France and Western Germany. Togo's apparent stability, its capitalist orientation and unwavering backing of Western positions in East-West cleavages, like the Hallstein Doctrine, meant to prevent international recognition of East Germany, were the main reasons. Thus, Togo was put on the drip of development aid for decades ${ }^{14}$.

Up to the end of the 1980s donors followed Eyadéma voluntarily in labeling Togo the "Switzerland of Africa" out of opportunistic reasons. However, Eyadéma's economic policy was neither development-oriented nor did the apparent domestic tranquility correspond to peaceful political cohabitation. It resembled rather graveyard peace, as revealed by the Sovereign National Conference of $1991^{15}$. In addition, economic growth was rather

14 Compared with public revenue, excluding grants of other governments or international aid organizations, ODA to Togo averaged to 62\% between 1985 to 1992; in the following years (1993 to 2002) it decreased only slightly to 57\% (World Bank: African Development Indicators, various years, Washington/DC: World Bank). Bilateral ODA of the Federal Republic of Germany (Western Germany) was given generously and out of proportion. It amounted to DM 600 Mio. between 1960 to 1989, supplemented by debt cancellation of DM 295.5 Mio. Even the formal disengagement of Western ODA from 1993 to 2008, because of gross human rights violation and bad government of the Eyadéma Regime, was not as radical as might be supposed in view of official declarations on aid conditionality. Even Germany, which increasingly fell apart with France over continuing aid to Lomé, paid between 1998 and 2003 about $€ 8$ to 10 million of bilateral aid to Togo (Kohnert 2011). Net ODA received as \% of central government expense in Togo from 2004 to 2012 averaged 45\% and reached its peak in 2009 with 100\%; see Table 3 (Annex).

${ }^{15}$ Interestingly enough, there existed at least four Togolese concentration camps for political detainees, situated in the northern parts of the country. Kazaboua, the most notorious, was constructed under dubious circumstances with assistance of a pioneer unit of the German Army, under the cover of bilateral military co-operation and armament grant in 1984, which triggered a controversial discussion in the German Bundestag (Bonn) in 1985. During the Sovereign National Conference of 1991 and the investigations of the Togolese Truth and Reconciliation Commission (CVJR, 2012) later-on this torture camp, as well as other misguided development projects like the infamous 30,000 ha 'model' cattle ranch 'Béna-Development', a kind of German PPP, had been singled out for especially cruel treatment of political prisoners and the local population (Kohnert 2011; CVJR-2012). 
externally driven then due to the government's own efforts. Togo gained relative prosperity up to the early 1980s mainly because of its role as a transit-economy for neighboring countries. This included not only landlocked Sahel-countries like Burkina Faso or Niger, but also Ghana and above all Nigeria which followed an import-substitution policy. Therefore, the effective demand for consumer goods of Togo's neighbors, was redirected to the informal (underground) market networks at Lomé.

Any efforts by the mostly clandestine opposition to expand freedom and democratic participation in the country were undermined. In July 1991, the Second Wind of Change in SSA and the successful democratization efforts in neighboring Benin, stimulated representatives of all social strata in Lomé to follow suit. They organized a Sovereign National Conference for a general account to rehabilitate the political past and to organize an new political order. The assembly opted for a semi-presidential system and elected an interim prime minister. Four months later, however, President Eyadéma ordered the army to attack the interim government, re-establishing his dictatorial power which lasted up to his death in 2005 when his son Faure Gnassingbé was installed by the military as his successor. The latter, known as modernizer, continued despite some democratic reforms almost unabated a kind of enlightened autocratic rule up to date, again assisted by the international donor community mainly out of overriding reasons of regional stability and combat of terrorism (Kohnert 2015).

Aid guidelines of donors that underwent considerable changes over time, were readily recognized formally by Lomé but outwitted by the seesaw policy of the ruling regime, facilitated by overriding considerations of global players in regional stability and security (Kohnert 2015; 2011). In view of growing deficits in the democratization process and the apparent unwillingness of the regime to give in, donors tried to bypass state authority by assisting national CSOs directly from 1993 to 2007. However, the coalition of political opposition and Civil Society Organizations to overcome autocratic rule utterly failed both due to the lack of unity and internal strife among the oppositional coalition and to the inconsistent and wagering aid-policies of major donors, as proved lastly during the presidentials of 2015.

\section{b. The development of civic agency in Togo}

For more than four decades, since the beginning of Gnassingbé rule in 1967, about $88 \%$ of Togolese citizens experienced no political alternation in their life but autocratic rule of just one family at the commanding heights of political, military and economic power of their 
country (Caritas France 2015:8). For an impartial view on the development potential of civic agency in Togo it is decisive to keep this always in mind.

The Gnassingbé regime was based on three pillars of power and repression: first, military and security services, organized like a Praetorian guard, as well as pro-Eyadéma militias, all dominated by members of the ethnic group of the president (Kabiyé). The military was upgraded with foreign assistance, notably of France, within the framework of secret pacts of mutual assistance. The second pillar was a politically instrumentalized occult belief system (occult despotism, witchcraft-violence against opponents), crucial but unfortunately mostly ignored by aid agencies, last but not least because it is usually hidden from outside observers, and the third, the political instrumentalization of traditional chieftaincies, local religious leaders and the provincial administration (prefects). In addition, the regime occupied the commanding heights of the economy in order to assure its financial base.

At least three peak-waves of democratic protest in Togo have been identified: 1991, 2005, 2010 by Franklin (2014) to which we have to add the most recent during the presidential of 2014-15 (Kohnert 2015). Whereas civic agency gathered a strong momentum in BF and finally overthrew the autocratic ruler, it was frustrated after repeated but powerless 'democratic revolutions' against the despotic Gnassingbé-Clan. As shown above, double-talk and misguided aid policy was one important, though hitherto neglected cause of this failure.

This notwithstanding, there are additional domestic reasons, mainly situated in the realm of the development potential of social capital, informal political institutions and CSO which could act in principle as counter-balancing political force. However, they were thwarted effectively by the Eyadéma regime as will be shown in detail below Yet, we should bear in mind that both external and internal factors are closely interrelated. Donor's reluctance over decades to implement aid-conditionality effectively was a precondition to enable the regime to consolidate its power over political and civic opposition.

The history of informal political and civil society institutions in Togo shows a rich base of 'traditional' as well as 'modern' institutions that participate actively on all levels of the society as will be shown in focusing on the five most important ones. The most powerful outcome of people's participation so far was the Sovereign National Conference of 1991 mentioned above. However, because the visions of this conference were dashed shortly afterwards by violent political oppression of the dictatorial Eydéma regime up to 2005, similar social initiatives were difficult to be re-established (Kohnert 2015: 15). 
Firstly, there are traditional political institutions, like the earth priests (chef de terre) and traditional chieftaincies that still wield an extraordinary power on village-level. They are even recognized as guardians of tradition and customary law by the Constitution. However, the role of traditional chiefs was adapted in decades of despotism to the needs of the ruling elite by the politics of 'authenticity' in the 1970s, i.e. the reference to (re-invented) traditional rules, and by the forced 'alignment' of chiefs in the National Confederation of traditional rulers of Togo (I'Union nationale des chefs traditionnels du Togo) created in August 1969. In addition, the legitimacy crisis left behind by decades of despotic rule and growing corruption in a fragile economic environment as well as the lacking decentralization policy and local elections postponed time and again by the government (the last being held in 1983) created barriers to good government and a transparent administration on the local level.

The same holds for traditional religious leaders, the second most important institution. African traditional religions, notably vodun in the Southern regions and occult belief systems all over Togo, still play an important role in everyday life. Their priests often act as estimated conflict mediators at the local level ${ }^{16}$. However, the instrumentalization of African religions and occult belief systems by the ruling powers for political means and political motivated witch-hunts as proofed so cunningly by the defunct Eyadéma regime (Kohnert 2011), discredited many religious leaders. Nevertheless, occult African belief systems are still an underlying current of all religious beliefs in Togo regardless of its spiritual orientation. Its instrumentalization is not restricted to the person of late General Eyadéma, nor to the ideological underpinning and legitimization of the worldly power of the head of state in general, but encompasses nearly all levels of public administration from the top, down to the level of simple district heads (Kohnert 2015: 6-7).

Thirdly, student organizations consider themselves as political avant-garde and act accordingly. Up to 2006, most of them were intimately linked to the ruling party. Thus, the High Council of Students' Associations and Movements (HACAME) degenerated into a progovernment militia which actively supported the incumbent's bloody, enthronement' in 2005. Since 2010, oppositional student organizations came to the fore which staged periodic anti-government demonstrations in the universities of Lomé and Kara. Their leaders suffered political persecution.

Fourthly, there are a large number of labour unions in Togo, but none of them has the strength or capacity to shape legislation. At least the unions succeeded in convincing the

\footnotetext{
$16 \mathrm{Ni}$-Mantche, the grand master of the vodun goodness Maman Kole in Southern Togo was counted in October 2014 by Jeune Afrique in an non-exhaustive ranking of the 15 most influent religious leaders in Africa as one of the most celebrated African vodun priests.
} 
government to continue paying subsidies for fuel and some staple food items as well as fertilizer so as to avoid a serious social crisis and political upheaval. Besides, there exist numerous professional representations of traders (notably the renown wealthy women cloth traders of Lomé, the 'Nana Benz'), farmers, lawyers, judges etc. However, they are either biased and close to the former unity party RPT/UNIR or of little political influence.

Last, but not least civil society organisations (CSO) mushroomed with the democratic renewal of the early 1990s. According to informed estimates there existed about 2,000 CSO in 2012, of which 638 were registered NGOs. Since 1986 the government promotes its federation within FONTGO (Féderation des Organisations Non-Gouvernmentales au Togo, 144 members in 2014). However, many CSOs were created in the 1990s on the initiative of the Gnassingbé regime in order to influence non-partisan political expression in Togo and to circumvent the suspension of development cooperation with state institutions in view of flagrant human rights violations. This is the reason why some of the most credible NGOs are not represented by this federation. Therefore, two concurrent umbrella organizations were formed: the UONGTO (Union des ONG du Togo, 124 members, 2014) in 1996 and in May 2012 the FNRRT (Fédération Nationale des Réseaux Régionaux du Togo). However, many, if not most CSO are covered job and income generating measures of their founders (so-called 'ONG-valises'). Their activities are mostly focused on Lomé and the Southern regions. Their target-groups, especially the poor and underprivileged, including women, are rarely allowed adequate rights of participation or self-determination ${ }^{17}$.

To be sure, this is not to put the blame for the lack of performance of Togolese CSO entirely on misguided aid policies and the repression by the autocratic regime. Besides there exist also self-inflicted failures. Above all civil society organizations tried to challenge the Gnassingbé regime in close cooperation with opposition parties ${ }^{18}$ mainly in opting for political alternation (changement, was their undifferentiated Leitmotif) and not for establishing unbiased democratic institutions that could be considered as sustainable base for a flourishing democracy (Okonofua 2015:95-96). In addition, internal strife and undue

\footnotetext{
17 Yet, there exist a handful of viable and independent national NGOs like ACAT-Togo (Action des Chrétiens pour l'Abolition de la Torture), which won the Human Rights price of the French Republic in 1997, the HRorganization LTDH (Ligue Togolaise des Droits de l'Homme), and the GF2D (Groupe de Réflexion et d'Action Femmes, Démocratie et Développement) concerned with gender equality. Some of them co-operate with political parties in broad antigovernment movements like the CST.

18 e.g. the broad opposition alliance Collectif Sauvons le Togo (CST), founded in April 2012), which was composed of civil-society organizations and political parties, led by the main opposition party Alliance Nationale pour le Changement (ANC), and the rainbow coalition of the moderate opposition 'Arc-en-ciel', originally meant to complement the CST, which merged later-on to create a common opposition alliance Combat pour l'Alternative Politique en 2015 (CAP 2015) for the presidentials of 2015.
} 
competition if not distrust of different clusters of the civil society contributed to its weakness.

\section{Conclusion}

Building up civic agency is crucial for a sustainable process of democratization. The development potential of civic agency in African countries and elsewhere depends on internal and external variables which are interdependent. The domestic factor rests to a large extent on the type and degree of repression as explained above as well as on the capacity of citizens to overcome fault lines of ethnicity, class, gender, religion and partisan politics in their own country. However, this domestic capacity can be enhanced also by global developments and networks like the spread of internet and mobile phones even in remote regions all over Africa, by international advocacy networks and last but not least by motivating successful protest movements in neighboring countries, like the Arab spring or the wave of Sovereign National Conferences in SSA in the early 1990s. Yet, civic agency can be diminished also, e.g. by trans-national waves of xenophobia like in Southern Africa in recent times and by despotic rulers who successfully apply a stick and carrot policy to divide their opponents. Because of a lack of sustainable solidarity and a united front CSOs thus are likely to become involuntary allies of the regime they want to contest.

Foreign influence on the development capacity of civic agency, both positive and negative, is often indirect, but not necessarily less effective. In many cases it is not visible at first sight, notably when it comes to its long-term effects. More often than not, it slips in under the radar screen of even well-intended aid-donors because the institutional memory both of development agencies and related research and evaluation institutions is usually quite short (Bierschenk / Elwert / Kohnert 1993). In contrast, the aftermath of misguided development policies and failed development projects remains often embodied in the memory of the local population concerned over generations. However, its long-lasting impact is considered by the donors only occasionally if at all.

In this study it is argued that the long-term effects of donor's double-talk, who openly promote democracy and freedom but covertly follow overriding hidden interest, are a neglected source of failure of civic protest and democratic revolutions in autocratic regimes. The differing outcome of 'democratic revolutions' in Togo and Burkina Faso - both 'aid darlings' for decades - serves to substantiate this thesis. 
Since colonial times BF has a long tradition of successful civil resistance to undemocratic rulers. This heritage even spread into the military which made for the Sankarist revolution in the 1980s. The latter, although short-lived and abated with assistance of foreign countries, still impacts positively on civic agency, up to the 'democratic revolution' in 2014 which ousted Compaoré after 27 years of autocratic rule. The impetus of democratic collective action prevailed despite countervailing foreign intervention over decades, i.e. the unwavering support of major donors for Compaoré, above all the former colonial power France.

Togo's civil society, on the other hand, was scared and suppressed over the past four decades by the Gnassingbé-regime with multiple, closely interacting means of repression, including the occult dimension. Nevertheless, the regime was consolidated by major aiddonors over decades as shown above. Legitimacy of the regime was derived largely externally, not by its own electorate. So far, about $88 \%$ of the living population did not experience political alternance in their life-time. The regime was based on three pillars of power and repression: first, military and security services, organized like a Praetorian guard, as well as pro-Eyadéma militias, all dominated by members of the ethnic group of the president (Kabiyé). The military was upgraded with foreign assistance, notably of France, within the framework of secret pacts of mutual assistance. The second pillar was a politically instrumentalized occult belief system (occult despotism, witchcraft-violence against opponents), and the third, the political instrumentalization of traditional chieftaincies, local religious leaders and the provincial administration (prefects). In addition, the regime occupied the commanding heights of the economy in order to assure its financial base.

To sum it up: Whereas civic agency gathered a strong momentum in BF and finally overthrew the autocratic ruler, it was systematically frustrated over decades and therefore resulted only in repeated but unsustainable 'democratic revolutions' against the despotic Gnassingbé-Clan. As shown above, double-talk and misguided aid policy was one important, though hitherto neglected cause of this failure. A systematic and holistic consideration is necessary for an unbiased evaluation of this hidden adverse impact of aid on collective action at the grass-roots. Therefore, a rethinking of temporal and disciplinary 'fault lines' in development politics as well as in development studies is essential. 


\section{Bibliographie}

AC (2015): Burkina Faso. The people take on the putschists. Africa Confidential. Vol. 56, Nr. 19, 24.09. 2015

Averill, G. (ed.), 1997: A Day for the Hunter, a Day for the Prey: Popular Music and Power in Haiti. Chicago: Chicago University Press

Barbière, Cécile (2014): French agencies score poorly in Aid Transparency Index. EurActiv.com, 10 Oct. 2014

Bingsten, Arne \& Sven Tengstam (2015): International Coordination and the Effectiveness of Aid. World Development, Volume 69, May 2015: 75-85

Birdsall, N., \& Kharas, H. (2010). Quality of official development assistance assessment. CGD report. Washington, DC: Center for Global Development. (nichts über Togo oder BF oder civic action/civil society)

Bierschenk, T. \& Elwert, G. \& Kohnert, D. (1993): The long-term effects of development aid Empirical studies in rural West Africa. Economics, Biannual Journal of the Institute for Scientific Co-operation, Tübingen, 47.1993.1:83 - 111

Blair, Harry (2004): Assessing civil society impact for democracy programmes: Using an advocacy scale in Indonesia and the Philippines. . Democratization, Volume 11, Issue 1, 2004:77-103

Bräutigam, D. \& Knack, S. (2004): Foreign aid, institutions, and governance in Sub-Saharan Africa. Economic Development and Cultural Change, 52 (2004) 2: 255-285

Bräutigam, Deborah (2000): Aid dependence and governance. EGDI. Report prepared for the Division for International Development Cooperation, Ministry for Foreign Affairs, Sweden

Brown, Stephen (2004): Foreign Aid and Democracy Promotion: Lessons from Africa. European Journal of Development Research, Vol.17, No.2, June 2005, pp.179-198

Bunk, Bettina \& Jasmin Lorch \& Jörg Wischermann (2015): Civil Society Organizations as supporters of Authoritarian Rule? A Cross-Regional Comparison (Vietnam, Algeria, Mozambique). GIGA Focus global, forthcoming.

Chouli, Lila. (2014): The popular uprising in Burkina Faso and the Transition. Review of African Political Economy, 42.143 (2015): 148. April 2015: 325-333

Chouli, Lila. (2014a): Social movement and the quest for alternatives in Burkina Faso. Chapter 7 of Sylla, N. S. (ed.)(2014): Liberalism and its discontents. Social movements in West Africa. CreateSpace Independent Publishing Platform.

Collier, Paul (2006): Is aid oil? An analysis of whether Africa can absorb more aid. World development, Volume 34, Issue 9, September 2006, Pages 1482-1497

Commeillas, David (2015) : Coup de Balai citoyen au Burkina Faso. Le Monde Diplomatique, April 2015:10-11

Davies, R. B. \& Stephan Klasen (2013): Of Donor Coordination, Free-Riding, Darlings, and Orphans: The Dependence of Bilateral Aid on Other Bilateral Giving. Center for Economic Studies \& Ifo Institute; CES-ifo, WP No. 4177 
Del Biondo (2015): Donor Interests or Developmental Performance? Explaining Sanctions in EU Democracy Promotion in sub-Saharan Africa. World Development, 75 (2015) 74-84

Djankov, Simeon \& Jose G. Montalvo, Marta Reynal-Querol (2008): The curse of aid. Journal of Economic Growth, September 2008, Volume 13, Issue 3, pp 169-194 ---

Ear, S. (2007): Does aid dependence worsen governance? International Public Management Journal, Volume 10, Issue 3, 2007: 259-286.

Earl, Jennifer (2003): Tanks, Tear Gas, and Taxes: Toward a Theory of Movement Repression. Sociological Theory, 21 (2003) 1:44-68

Eberlei, Walter (2014): African Social Movements vs. Civil Societies in Africa? Forschungsjournal Soziale Bewegungen - PLUS, Supplement zu Heft 3/2014

Engels, Bettina (2015): Different means of protest, same causes: popular struggles in Burkina Faso. Review of African Political Economy, 42.143 (2015): 92-106

Engels, Bettina (2015a) Contentious Politics of Scale: The Global Food Price Crisis and Local Protest in Burkina Faso. Social Movement Studies: Journal of Social, Cultural and Political Protest, 14:2, 180194

Engels, Bettina (2015b): Political Transition in Burkina Faso: the Fall of Blaise Compaoré. Governance in Africa, 2(1): 3, pp. 1-6

Felice, de, Daminano (2015): Diverging visions on political conditionality: The role of domestic politics and international socialization in French and British aid. World Development, 75 (2015):26-45

Franklin, James (2014): Democratic revolutions and those that might have been: Comparing the outcomes of protest waves under authoritarian rule. APSA 2014 Annual Meeting paper. Ohio Wesleyan University.

Frère, Marie-Soleil \& Pierre Englebert (2015): Briefing: Burkina Faso-the Fall of Blaise Compaoré. African Affairs, July 2015114 (456): 295-307

Fowler, Alan (2009): Civic agency. In: Helmut K. Anheier, Stefan Toepler (eds.), International Encyclopedia of Civil Society. Springer Science \& Business Media, 2009: 150-155

Gabas, J.J. et al (1997): The effectiveness of French Aid - Burkina Faso. In: Carlsson, Gloria et al: Foreign aid in Africa: Learning from country experience. Uppsala: Nordic Africa Institute, 1997:3664.

Hackenesch, Christine (2015): It's Domestic Politics, Stupid! EU Democracy Promotion Strategies Meet African Dominant Party Regimes. World Development, 75.2015: 85-96

Haskin, Jonathan (2015): Burkina Faso's Hollow Revolution. Univ. of Pennsylvania, The Spectrum

Hearn, J., and M. Robinson (2000). 'Civil Society and Democracy Assistance in Africa'. In P. Burnell (ed.), Democracy Assistance: International Co-operation for Democratization. London : Frank Cass, 2000 :

Hoeffler, Anke \& Verity Outram (2009): Need, Merit or Self-Interest-what determines the Allocation of Aid? Oxford: CSAE WPS 9, July 2008.

Kangoye, T. (2013): Does aid unpredictability weaken governance? Evidence from developing countries. The Developing Economies, Volume 51, Issue 2, pages 121-144, June 2013

Knack. Stephen (2004): Does foreign aid promote democracy? International Studies Quarterly, Volume 48, Issue 1, pages 251-266, March 2004.(Togo \& BF included in sample) 
Knack. Stephen (2001): Aid Dependence and the Quality of Governance: Cross-Country Empirical Tests. Southern Economic Journal, Vol. 68, No. 2 (Oct., 2001), pp. 310-329

Kohnert, Dirk (2015): Togo: recent political and economic development. Forthcoming as "BTI 2016 Togo Country Report" in: BTI 2016. Political Management in International Comparison. Gütersloh: Bertelsmann Foundation

Kohnert, Dirk (2011): Togo: Thorny transitions and misguided aid at the roots of economic misery. IN: Saine, Abdoulaye / N 'Diaye, Boubacar / Houngnikpoet, Mathurin (eds.) (2011): Elections and democratization in West Africa 1990 - 2009. Trenton: Africa World Press (AWP), 2011: 179-210

Kohnert, D. (2011a): Cultures of Innovation of the African Poor - Common roots, shared traits, joint prospects? On the articulation of multiple modernities in African societies and Black Diasporas in Latin America. In: LeMeur, Pierre-Yves / Schareika, Nik / Spies, Eva (eds.)(2011): Auf dem Boden der Tatsachen. Festschrift für Thomas Bierschenk. Köppe: Köln: Mainzer Beiträge zur Afrikaforschung 28, pp. 241-262

Kohnert, Dirk (2005): Die UEMOA und die CFA-Zone. Eine neue Kooperations-Kultur im frankophonen Afrika? In: Nabers, Dirk / Ufen Andreas (eds.): Regionale Integration - Neue Dynamiken in Afrika, Asien und Lateinamerika. Schriften des Deutschen Übersee-Instituts, Nr. 65, Hamburg, DÜl, 2005:115-136

Kohnert, Dirk (2004): Election observation in Nigeria and Madagascar - Diplomatic vs. technocratic bias. Review of African Political Economy, 31 (2004) 99: 83-101

Kohnert, Dirk (2004a): Country Concepts and the Rational Actor Trap - Limitations to Strategic Management of International NGOs. Munich: RePEc / MPRA paper No. 981

Kohnert, D. \& Preuss, Hans (2003): NGO-work under changed conditions - Country concepts of DWHH - German Agro Action. Development and Change (D+C), 30.2003:10, pp. 380-382

Obadare, Ebenezer \& Wendy Willems (eds.)(2014):Civic agency in Africa. Arts of resistance in the 21st century. London: James Currey

Okonofua, Benjamin A. (2015): Democratic governance in the 'new' Republic of Togo. Chap. 6, IN: Metelits, Claire \& Matti, Stephanie (eds.): Democratic contestation on the margings. Regimes in small African countries. Lexington Books: 2015: 85-98

Prause, Louisa (2013): Mit Rap zur Revolte: Die Bewegung Y'en a marre. Prokla Jg. 43 (2013) 1: 23-41

Resnick, Danielle \& Nicolas van de Walle (eds.)(2013): Democratic trajectories in Africa: Unraveling the impact of foreign aid. Oxford: Oxford University Press, 2013

Resnick, Danielle (2012): Foreign aid in Africa: Tracing channels of influence on democratic transitions and consolidation. WIDER Working Paper 2012/15

Rogerson, Andrew \& Suzanne Steensen (2009): Aid Orphans: Whose Responsibility? Paris: OECD Development Co-operation Directorate, Development Brief 1/2009

Rupley, L. \& Lamissa Bangali \& Boureima Diamitani (2013): Historical Dictionary of Burkina Faso. Scarecrow Press.

Van Wyk, Coen (2015): Compaore's Burkina Faso exit has implications for Africa's other longentrenched rulers: in the final analysis - issue in focus. Africa Conflict Monitor, Jan 2015: 78-83

\section{Annex}


Tabel 1: Net ODA received (\% of GNI) Burkina Faso and Togo: 1980 - 2013

\begin{tabular}{|l|l|l|l|l|l|l|l|l|l|l|l|}
\hline $\begin{array}{l}\text { Country / } \\
\text { year }\end{array}$ & 1980 & 1981 & 1982 & 1983 & 1984 & 1985 & 1986 & 1987 & 1988 & 1989 & $\boldsymbol{a v}$ \\
\hline BF & 10.9 & 12.2 & 12.1 & 11.4 & 12.6 & 12.2 & 13.2 & 11.4 & 11.0 & 10.2 & $\mathbf{1 1 , 6}$ \\
\hline Togo & 8.2 & 6.8 & 9.8 & 15.4 & 15.9 & 15.3 & 16.7 & 10.1 & 15.4 & 15.2 & $\mathbf{1 2 , 9}$ \\
\hline
\end{tabular}

\begin{tabular}{|l|l|l|l|l|l|l|l|l|l|l|l|}
\hline $\begin{array}{l}\text { year } \\
\text { (cont. })\end{array}$ & 1990 & 1991 & 1992 & 1993 & 1994 & 1995 & 1996 & 1997 & 1998 & 1999 & av \\
\hline BF & 10.6 & 13.4 & 19.4 & 20.2 & n.a & 23.0 & 16.1 & 15.1 & 14.3 & 13.2 & $\mathbf{1 6 , 1}$ \\
\hline Togo & 16.2 & 12.7 & 13.4 & 7.9 & n.a & 15.1 & 10.8 & 8.5 & 8.2 & 4.7 & $\mathbf{1 0 , 8}$ \\
\hline
\end{tabular}

\begin{tabular}{|l|l|l|l|l|l|l|l|l|l|l|l|l|l|l|l|}
\hline $\begin{array}{l}\text { year } \\
\text { (cont.) }\end{array}$ & 2000 & 2001 & 2002 & 2003 & 2004 & 2005 & 2006 & 2007 & 2008 & 2009 & 2010 & 2011 & 2012 & 2013 & av \\
\hline BF & 6.9 & 14.6 & 13.8 & 12.9 & 13.4 & 12.7 & 15.4 & 14.1 & 12.0 & 13.0 & 11.8 & 9.3 & 10.0 & 8.1 & $\mathbf{1 2 , 0}$ \\
\hline Togo & 5.5 & 3.5 & 3.5 & 3.0 & 3.4 & 4.0 & 3.7 & 4.9 & 11.8 & 17.8 & 14.6 & 17.0 & 7.3 & 6.0 & $\mathbf{7 , 6}$ \\
\hline
\end{tabular}

Legend: Net ODA as \% of GNI not available for 1994, 2014; Western ODA to Togo was officially suspended from 1993 to 2008 because of HR-violations. Source: World Development Indicators, World Bank, 2015

Table 2: Net ODA received as \% of central government expense in BF (2002 - 2012)

\begin{tabular}{|l|c|c|c|c|c|c|c|c|c|c|c|c|}
\hline year & 2002 & 2003 & 2004 & 2005 & 2006 & 2007 & 2008 & 2009 & 2010 & 2011 & 2012 & av \\
\hline$B F$ & 122,7 & 122,9 & 116,0 & 110,6 & 122,2 & 101,4 & 98,8 & 102,4 & 99.3 & 74.7 & 71.4 & 112.1 \\
\hline
\end{tabular}

Legend: not available for 1980-2001, 2013-15;

Source: World Development Indicators, World Bank, 2015

Table 3: Net ODA received as \% of central government expense in Togo (2002 - 2012)

\begin{tabular}{|l|l|l|l|l|l|l|l|l|l|l|l|l|}
\hline year & 2002 & 2003 & 2004 & 2005 & 2006 & 2007 & 2008 & 2009 & 2010 & 2011 & 2012 & av \\
\hline Togo & n.a. & n.a. & 21,9 & 24,3 & 20,9 & 28,0 & 75,4 & 100,5 & 88.3 & 92.7 & 34.3 & 45.2 \\
\hline
\end{tabular}

Legend: not available for 1980-2003, 2013-15;

Source: World Development Indicators, World Bank, 2015

Table 4: Net ODA received Togo: 1970 - 1979 (\% of GNI, Mio, current US \$) 


\begin{tabular}{|l|r|r|r|r|r|r|r|r|r|r|r|r|}
\hline year & 1970 & 1971 & 1972 & 1973 & 1974 & 1975 & 1976 & 1977 & 1978 & 1979 & \\
\hline ODA & 17,00 & 19,30 & 21,60 & 25,80 & 38,60 & 41,70 & 42,80 & 63,90 & 101,90 & n.a & \\
\hline GNI & 276 & 282 & 320 & 392 & 527 & 617 & 659 & 732 & 854 & & \\
\hline ODA,\% GNI & 6,15 & 6,80 & 6,75 & 6,58 & 7,32 & 6,76 & 6,5 & 8,73 & 11,9 & & \\
\hline
\end{tabular}

Source: World Development Indicators, World Bank, 2015

Table 5: Togo - ODA and Aid Received, 1960 - 1980 (Mio., Current US \$)

\begin{tabular}{|l|r|r|r|r|r|r|r|r|r|r|r|c|}
\hline year & 1960 & 1961 & 1962 & 1963 & 1964 & 1965 & 1966 & 1967 & 1968 & 1969 & 1970 & av \\
\hline Togo & 0.03 & 2.53 & 3.56 & 5.70 & 13.82 & 12.43 & 10.88 & 12.87 & 18.92 & 17.49 & 17.00 & 8.83 \\
\hline
\end{tabular}

\begin{tabular}{|l|c|c|c|c|c|c|c|c|c|c|c|}
\hline $\begin{array}{l}\text { year } \\
\text { (cont.) }\end{array}$ & 1971 & 1972 & 1973 & 1974 & 1975 & 1976 & 1977 & 1978 & 1979 & 1980 & $a v$ \\
\hline Togo & 19.32 & 21.65 & 25.83 & 38.69 & 41.78 & 42.93 & 64.19 & 102.47 & 109.69 & 90.98 & 55.75 \\
\hline
\end{tabular}

Source: Earthtrends, World Resources Institute (WRI), 2015; 